\title{
On Testing for Speculative Bubbles
}

\author{
Robert P. Flood; Robert J. Hodrick
}

The Journal of Economic Perspectives, Vol. 4, No. 2. (Spring, 1990), pp. 85-101.

Stable URL:

http://links.jstor.org/sici?sici=0895-3309\%28199021\%294\%3A2\%3C85\%3AOTFSB\%3E2.0.CO\%3B2-1

The Journal of Economic Perspectives is currently published by American Economic Association.

Your use of the JSTOR archive indicates your acceptance of JSTOR's Terms and Conditions of Use, available at

http://www.jstor.org/about/terms.html. JSTOR's Terms and Conditions of Use provides, in part, that unless you have obtained prior permission, you may not download an entire issue of a journal or multiple copies of articles, and you may use content in the JSTOR archive only for your personal, non-commercial use.

Please contact the publisher regarding any further use of this work. Publisher contact information may be obtained at http://www.jstor.org/journals/aea.html.

Each copy of any part of a JSTOR transmission must contain the same copyright notice that appears on the screen or printed page of such transmission.

JSTOR is an independent not-for-profit organization dedicated to and preserving a digital archive of scholarly journals. For more information regarding JSTOR, please contact support@jstor.org. 


\title{
On Testing for Speculative Bubbles
}

\author{
Robert P. Flood and Robert J. Hodrick
}

$\Omega$

he possibility that movements in prices could be due to the self-fulfilling prophecies of market participants has long intrigued observers of free markets. Such self-fulfilling prophecies are often called "bubbles" or "sunspots" to denote their dependence on events that are extraneous to the market. The folklore of such episodes includes the tulip bubble, the South Sea bubble and the Mississippi bubble (all discussed in Peter Garber's article in this issue), and the increase in equity prices during the "Roaring 20's" followed by the 1929 crash (discussed in Eugene White's article in this journal). More recently, the rise and crash of stock prices from 1982 to 1987 , the appreciation of the dollar on foreign exchange markets that peaked in 1985, and sudden housing price increases in California and Massachusetts have been attributed to speculative bubbles. The idea that bubbles might exist is often traced to John Maynard Keynes's (1936) description of an equity market as an environment in which speculators anticipate "what average opinion expects average opinion to be," rather than focusing on things fundamental to the market.

If bubbles exist in asset markets, market prices of assets will differ from their fundamental values. Markets would not necessarily be allocating the savings of individuals to the best possible investment uses. Public policies might be designed to attempt to rid the markets of bubbles. Although these problems have been discussed for a long time, academic economists conducted relatively little formal empirical analysis of actual markets until recently, probably because economists' analytical and statistical tools were inadequate. Since economic theory placed essentially no restric-

- Robert P. Flood is Senior Economist, International Monetary Fund, Washington, D.C., and Robert J. Hodrick is Professor of Finance, Kellogg Graduate School of Management, Northwestern University, Evanston, Illinois. Both authors are Research Associates of the National Bureau of Economic Research, Cambridge, Massachusetts. 
tions on how agents formed expectations of future prices, empirical analysts had little direction for studying the possibility of self-fulfilling prophecy. The widespread adoption of the rational expectations hypothesis provided the required underpinning for theoretical and empirical study of the issues. ${ }^{1}$

This paper surveys the current state of the empirically-oriented literature concerning rational dynamic indeterminacies, by which we mean a situation of selffulfilling prophecy within a rational expectations model. Empirical work in this area concentrates primarily on indeterminacies in price levels, exchange rates and equity prices. $^{2}$ To provide a common ground for later analysis, we first examine a particular type of explosive indeterminacy, usually called a rational bubble, in an example of the market for equities. Then, we consider empirical work relating to price-level and exchange-rate indeterminacies and empirical studies of indeterminacies in stock prices. Finally, we take up some interpretive issues.

\section{Some Intuition about Rational Bubbles}

Many rational expectations models have an indeterminate aspect, as explained by William Brock (1974), John Taylor (1977), and Robert Shiller (1978). Usually, this indeterminacy arises when the current decisions of agents depend both on the current market price and on their expectations of future prices. For example, consider a simple economic model in which investors' demands for an equity depend on the expected return on the equity. If a fixed amount of the equity is outstanding, the current price is determined by the intersection of investor demands with the existing supply. But, equilibrium demand depends upon the current equity price and the beliefs of agents about equity prices in the future, since realized returns depend on the cost of the equity today, on its resale value in the future and on any intermediate dividends paid to holders of the stock. Since the current price depends on the expectation of the future price and the expectation of the future price depends on the current price, the simple theory cannot determine the market price. It only determines sequences of prices. Only one sequence is the market fundamental price path, and the others will have price bubbles.

In such circumstances, economic models require additional restrictions if they are to make firm predictions about the current market price. If plausible theoretical restrictions are added to the model, it is possible for a researcher to exclude a large number of price paths, narrowing the field to a unique path. For example, Jean Tirole (1985) demonstrates that real asset prices will be unique and will depend only on market fundamentals in an economy with a finite number of rational infinitely-lived

\footnotetext{
${ }^{1}$ Rational expectations is the requirement that the subjective expectations of the agents in an economic model be identical to the mathematical expectations of the model that are produced by the exogenous sources of uncertainty interacting with the behavior of the agents.

${ }^{2}$ Olivier Blanchard and Mark Watson (1982) also study the market for gold.
} 
traders. ${ }^{3}$ Since the assumption of infinitely-lived agents is controversial, some economists find this anti-bubble logic uncompelling. Tirole (1985) also explores an overlapping generations model of real asset pricing that does not exclude explosive indeterminacies as equilibrium phenomena, but he finds that they occur only if the rate of growth of the economy is higher than the steady state rate of return on capital. Price level models that are consistent with many researchers' prior beliefs but that still fail to exclude explosive indeterminacies are discussed by William Brock (1974) and subsequently by Maurice Obstfeld and Kenneth Rogoff $(1983,1986)$. Interestingly, explosive price level indeterminacies are much harder to rule out with a priori theoretical arguments than are indeterminacies concerning real asset prices. Nonexplosive indeterminacies in rational expectations models, which we call sunspots, are even harder to rule out with theoretical arguments than are explosive indeterminacies.

Many researchers argue that empirical tests for bubbles and sunspots are uninteresting because they can be ruled out by certain types of rational economic theories. Should these researchers still be interested in empirical tests of bubbles? We answer yes, primarily because bubble tests are an interesting specification test of the model. Since bubbles and sunspots arise in economic models that incorporate market fundamentals, tests for these indeterminacies require correct specification of market fundamentals. Bubble tests examine a composite null hypothesis of no bubbles and correctly specified market fundamentals, which must be construed broadly to be both the data series and the equations that constitute the economic model. Since bubble tests can only legitimately be done on models that are not rejected by the data, researchers must first conduct a battery of diagnostic tests. Bubble tests may be powerful at detecting misspecifications of the model, even if it has passed other specification tests.

It is our contention that no econometric test has yet demonstrated that bubbles are present in the data. In each case, misspecification of the model or alternative market fundamentals seems the likely explanation of the findings.

\section{A Common Theoretical Framework for Analyzing Bubbles}

If people in the economy are not averse to risk, and if they discount future utility at a constant rate $r$, all assets would have the same constant expected real return in equilibrium. The price of one equity share, $q_{t}$, which is the sacrifice that is made to purchase the asset, would be equal to the expected discounted present value of the dividend accruing to ownership of the equity share during the ownership period, $d_{t+1}$, plus the price at which the share can be sold at the end of the ownership period, $q_{t+1}$.

\footnotetext{
${ }^{3}$ No one thinks agents actually live forever, but families can be effectively linked across generations by intergenerational transfers and bequests. See Barro (1989) for a discussion of this issue as it applies to the effects on the economy of government budget deficits.
} 
These are the benefits from owning the asset. Hence,

$$
q_{t}=E_{t}\left(d_{t+1}+q_{t+1}\right) /(1+r)
$$

where $E_{t}\left(d_{t+1}+q_{t+1}\right)$ denotes the expected value of the future dividend and the future price conditional on information available to people at time $t$. A typical asset pricing formula can be derived from equation (1) by a recursive process. Update equation (1) by one time period and substitute the resulting expression for $q_{t+1}$ into the original equation. This gives

$$
q_{t}=E_{t}\left[d_{t+1}+E_{t+1}\left(d_{t+2}+q_{t+2}\right) /(1+r)\right] /(1+r) .
$$

Then, update equation (1) again, and substitute for $q_{t+2}$ into equation (2). Do this repeatedly. Next, use the law of iterated expectations, $E_{t}\left(E_{t+1}\left(d_{t+2}\right)\right)=E_{t}\left(d_{t+2}\right)$, which recognizes that the expected value today of what we will expect about the future when we have more information tomorrow is simply what we expect about the future today with less information. The eventual result with an infinite number of substitutions is that the current price equals the expected present value of all future dividends:

$$
q_{t}^{f}=\sum_{i=1}^{\infty}[1 /(1+r)]^{i} E_{t}\left(d_{t+i}\right)
$$

We attach a superscript $f$ to this price because we define it to be the market fundamentals price for this model since we assumed in its derivation that the discounted value of the expected price infinitely far in the future is zero.

Equation (3), however, does not give the only mathematical solution to equation (1). To characterize other solutions let the market price be the fundamentals price plus something else that we will call a bubble, which we denote with $B_{t}$ :

$$
q_{t}=q_{t}^{f}+B_{t}
$$

A bubble thus represents a deviation of the current market price of the asset from the value implied by market fundamentals. If the market price in equation (4) is to satisfy equation (1), the current value of the bubble must be the expected discounted value of the future bubble next period. That is,

$$
B_{t}=E_{t}\left(B_{t+1}\right) /(1+r) \text {. }
$$

This shows that a bubble can be a possible outcome of this model, as long as the bubble represents an expectation that the bubble will continue. Apparently, market prices can be sternly sensible or very silly indeed. The definition of a bubble is sometimes rewritten as:

$$
B_{t+1}=B_{t}(1+r)+b_{t+1}
$$


where $b_{t+1}=B_{t+1}-E_{t}\left(B_{t+1}\right)$. According to the terminology adopted by Olivier Blanchard (1979), Robert Flood and Peter Garber (1980b) and Blanchard and Mark Watson (1982), $B_{t}$ is a bubble in the equity price, and $b_{t+1}$ is the innovation in the bubble at time $t+1$ which has mean zero. Hence, if bubbles exist, they must be expected to grow at the real rate of interest. ${ }^{4}$

Theory is helpful in thinking about whether terms like $B_{t}$ can exist in rational markets. For example, William Brock (1982) notes that if the researcher thinks that the market can be analyzed by considering the maximization problem of a competitive, representative, infinitely-lived investor, there is a terminal condition (known as a transversality condition) that allows the analyst to deduce that rational bubbles are absent. $^{5}$

To understand why this prevents bubbles from occurring, consider the consequences of several investment strategies available to a competitive agent. First, since the representative agent lives forever, one possible investment is the buy and hold forever strategy. This produces a marginal gain at time $t$ equal to the expected discounted value of all future dividends, which is the market fundamentals price. If the actual price of the asset were less than the fundamentals price, the representative agent could increase utility by buying the asset and planning to hold it forever. This increased demand would raise the market price, eliminating the bubble. On the other hand, if an asset's price exceeded the market fundamentals price, rational competitive agents would sell the asset because the utility gain would exceed the utility lost from expecting to hold it forever. The decrease in demand would cause the market price to fall.

Thus, if one is willing to argue for a representative investor model, then a test for bubbles is a test of the underlying model; and a rejection of the hypothesis that no bubbles exist is a rejection of the representative investor model, including the transversality condition.

Another theoretical argument against bubbles is provided by Behzad Diba and Herschel Grossman $(1987,1988)$ who note that bubbles in real stock prices can never be negative. From equation (5), which provides the time path of a bubble, a negative bubble at time $t$ would be expected to grow more negative over time. From equation (4), this implies that the market stock price would be expected to be negative within finite time, since the market fundamentals price cannot grow that fast. Since you can always walk away from your investment in the stock market, the stock price cannot be negative. Hence, negative bubbles are inconsistent with rational expectations. Ruling out negative bubbles is important since it implies that if a bubble ever is zero it cannot start again because the innovation in the bubble, $b_{t+1}$, which must have mean zero,

\footnotetext{
${ }^{4}$ The bubble process is the homogenous part of the solution to the difference equation (1). Edwin Burmeister, Robert Flood and Peter Garber (1983) explain several indeterminacies discussed in the literature in terms of the homogenous part of the solution. This type of indeterminacy is explosive since $(1+r)>1$.

${ }^{5}$ See Maurice Obstfeld and Kenneth Rogoff (1983) for additional intuition and more formal discussion of the transversality condition and for additional references to the mathematical literature on the subject.
} 
would not be mean zero since there would only be one way to go. Hence, any bubbles currently present would have had to start at the initiation of the market.

Most of the empirical work on bubbles is concerned with the theoretical indeterminacy introduced above. The next two sections explore the empirical implications of this type of indeterminacy in two settings: models of price levels and exchange rates and of equity pricing.

\section{Price-Level Bubble Tests}

We now turn our attention to price-level bubble tests because they were the first empirical tests, and methodological advances were built upon them. Indeterminacies in theoretical models of the price level usually result when the demand for nominal assets depends on the expected rate of inflation. Robert Flood and Peter Garber (1980b) developed an empirical test for such bubbles in a monetary model of the German hyperinflation first studied by Phillip Cagan (1956). Their model consists of a money demand equation that is linear in natural logarithms, a money supply rule, and money market equilibrium. The equation for money market equilibrium that combines supply and demand is

$$
m_{t}-p_{t}=\beta-\alpha\left[E_{t}\left(p_{t+1}\right)-p_{t}\right]+v_{t}, \quad \alpha>0 .
$$

The left-hand side of this equation represents the logarithm of actual real money supply with $m_{t}$ equal to the logarithm of the nominal money supply at time $t$ and $p_{t}$ equal to the logarithm of the price level at time $t$. The right-hand side of the equation states that the demand for real money balances deviates from a constant level $\beta$ when there is expected inflation, which decreases the demand for money, or when other determinants given by the random error term $v_{t}$ change. The parameter $\alpha$ measures the sensitivity of the demand for money with respect to expectations of inflation. The equation is simple because the determinants of money demand other than expected inflation are thought to be effectively constant in a hyperinflation.

The "market fundamentals" solution for the price level can be found by analogy to the previous example of equity prices. In this case, the general price level $p_{t}$ plays the role previously held by the equity price $q_{t}$. To find the market fundamentals solution, solve equation (7) for $p_{t}$ and think of $k_{t}=\left(m_{t}-\beta-v_{t}\right) /(1+\alpha)$ as playing the role of dividends paid at time $t$. Also, think of $\alpha /(1+\alpha)$ as the counterpart of $1 /(1+r)$. By analogy with equation (2), the market fundamentals solution to equation (7) is:

$$
p_{t}^{f}=\sum_{i=0}^{\infty}[\alpha /(1+\alpha)]^{i} E_{t}\left(k_{t+i}\right)
$$

Equation (8) states that the price level at any given time is determined by the discounted expected values of factors affecting the supply of money, $m$, relative to the demand for money (as determined by demand parameter $\beta$ and the factors in $v_{t}$ ). As before, this formulation does not give all of the possible solutions to equation (7). A 
self-fulfilling price level bubble can be added to the market fundamental price if the current value of the bubble depends on the discounted expectation of the future value of the bubble such that $E_{t}\left(B_{t+1}\right)=[1+(1 / \alpha)] B_{t}$, where the reciprocal of $\alpha /(1+\alpha)$ is $[1+(1 / \alpha)]$. Instead of exploding at the real rate of interest, this model predicts that logarithmic price level bubbles must explode at the rate $(1 / \alpha)$.

Although indeterminacies such as $B_{t}$ had been discussed in the theoretical literature, Flood and Garber's (1980b) attempt to identify, estimate and test for a bubble process removed it from the realm of pure theory and inserted it into empirical economics. Flood and Garber assume that the nominal money supply is exogenous and investigate its time series properties which are necessary in the estimation of the reduced form equation. They also assume that $v_{t}$ follows a random walk. This simplifies the forecasting problem in equation (8). They estimate a reduced form equation for the rate of inflation assuming that a nonstochastic bubble process infects the logarithm of the price. Consequently, the bubble process satisfies $B_{t}=$ $B_{0}[1+(1 / \alpha)]^{t}$, and the no bubbles hypothesis is the coefficient restriction that the initial bubble $B_{0}=0$. A representative reduced form equation from their study is

$$
p_{t}-p_{t-1}=\delta_{0}+\delta_{1} \mu_{t-1}+\cdots+\delta_{k} \mu_{t-k}+B_{0}[1+(1 / \alpha)]^{t}+\epsilon_{t}
$$

where $\mu_{t}$ is the money growth rate and $v_{t}=v_{t-1}+\epsilon_{t}$. Flood and Garber found no evidence to reject the hypothesis that the parameter $B_{0}$ was equal to zero, although there are problems with their empirical methodology.

Flood and Garber mention three potential methodological weaknesses of their study. First, they assume that money is exogenous which rules out feedback from previous inflation to current money supply creation as would happen when the government prints money to finance real expenditures. Second, they allow only for a deterministic bubble process. Finally, for reasons that will be explained presently, their statistical inference does not have solid foundations in asymptotic distribution theory.

Edwin Burmeister and Kent Wall (1982) use the Flood and Garber data and the Cagan model to address the first two issues. They allow money growth to depend on past money growth and past inflation, thus relaxing the exogeneity assumption, and they allow a constant nonzero variance for the innovation in the bubble $b_{t}$, which allows the bubble to be stochastic. But, although both the Flood-Garber and the Burmeister-Wall studies develop consistent parameter estimates, they lack convincing tests of the no bubbles hypothesis because of an exploding regressor problem. Because estimation is conducted under the alternative hypothesis that bubbles are present in the economy, the reduced form regression (9) has $[1+(1 / \alpha)]^{t}$ as the regressor associated with the parameter $B_{0}$, the initial value of the bubble. This regressor is exploding quite fast as $t$ increases; indeed, it explodes so fast that the information content of its most recent observation never goes to zero as a fraction of the information content of all previous observations. This situation makes it easy to prove consistency of the estimator of $B_{0}$ since convergence is quick, but it presents serious problems for testing hypotheses concerning $B_{0}$. The information structure of the exploding regressor ensures that any time series sample no matter how large is always a small sample, and standard central limit theorems do not apply. 
The first attempt at circumventing the asymptotic distribution theory problem was made by Flood, Garber and Louis Scott (1984) who use the fact that several countries experienced simultaneous hyperinflations following World War I to test the hypothesis that no bubbles have occurred in a time series-cross section framework. An asymptotic distribution for the bubble coefficient in equation (9) is obtained by approaching the hypothetical limit in the cross-sectional dimension; that is, by thinking that the number of countries is going to infinity rather than assuming that time periods are going to infinity. Unfortunately, Flood, Garber and Scott have data for only three simultaneous hyperinflations. While they reject the hypothesis of no bubbles in the three simultaneous hyperinflations, their appeal to large sample distribution results is probably suspect.

More recently, the empirical approach to testing the no bubbles hypothesis has taken a second, indirect approach. West (1987a) developed the indirect approach in an application to the stock market, which is discussed below. Alessandra Casella (1986) applies the West-style test to the German hyperinflation data, and it is in that context that we introduce the test. The fundamental insight involves estimating the parameters of a reduced-form price equation by two different methods.

In Casella's application to the German hyperinflation, the bubble test requires two estimates of $\alpha$, the sensitivity of money demand with respect to the expected rate of inflation. The first estimation method delivers consistent (but inefficient) estimates of the parameter and its standard error regardless of the presence of bubbles. This is done by instrumental variable estimation of the money demand function (7). The second approach delivers parameter estimates and standard errors that are consistent and efficient if bubbles are absent, but that are inconsistent if bubbles are present. This second approach requires simultaneous estimation of a market-fundamentals forecasting process and a reduced form equation like equation (9), but without the bubble process present. Estimation is done subject to the rational expectations cross equation restrictions, as derived by Lars Hansen and Thomas Sargent (1981). The cross equation restrictions arise because the $\delta$ parameters in equation (9) are functions of $\alpha$ and the parameters that describe the money supply process.

The two estimates of $\alpha$ and their standard errors will yield numerically different values, which motivates a Hausman (1978) specification test. This test investigates whether the differences in the estimated coefficients are due to sampling error or to a bias in the second estimates. For example, if the market price contains a bubble that is correlated with some of the market fundamentals, then the second method which leaves the bubble process out of the reduced form estimation will yield biased coefficient estimates on the included variables. ${ }^{6}$ In this circumstance, when all other elements of the model are thought to be correct and are therefore inserted into the maintained hypothesis, the Hausman test becomes a bubble test. One of the strengths

\footnotetext{
${ }^{6}$ The bubble need not be correlated with market fundamentals to apply the Hausman test. While a bias may be created by correlation of the bubble innovations with innovations in any of the fundamental variables, it may also be created by the bubble's mean biasing the estimate of the constant in the reduced form or because the improperly excluded bubble has exploding variance. See Casella (1986).
} 
of this type of test is that the researcher does not have to specify an ad hoc restriction on the variance of $b_{t}$-the weaknesses of the test will be discussed below.

When Casella implements her version of the West bubble test on the German data, her results are consistent with the presence of price-level bubbles if the money supply is maintained to be an exogenous process relative to inflation, but they are consistent with the no bubbles hypothesis if the money supply is modeled as an endogenous process in which case there is feedback from past inflation to current money creation. Since the money supply is exploding in a hyperinflation, lack of feedback implies an odd and perhaps implausible behavior of the monetary authority.

\section{Exchange Rate Bubble Tests}

A bubble that appears in a theoretical model of the price level, which is the value of goods in terms of a particular currency, usually appears also in a model of the foreign exchange value of that currency. Consequently, many models of price level bubbles and exchange rate bubbles have points of equivalence, as Kenneth Singleton (1987) notes.

Richard Meese (1986) applies the West (1987a) bubble test to the U.S. dollar values of the deutschemark and the pound sterling exchange rates using a two-country money market equilibrium model to determine exchange rates. ${ }^{7}$ In his framework, money demand in each country depends on real income and the interest rate, the interest rate differential depends on the expected rate of change of the exchange rate, and deviations from purchasing power parity are a random walk. These equations may be solved for an exchange rate equation in which the current exchange rate depends on current and expected future money supplies and real incomes, which provides the market fundamentals solution. The West test indicates very strong evidence of bubbles in these exchange rates during the period from October 1973 to November 1982.

Kenneth West (1987b) conducts some additional bubble tests on the deutschemark-dollar exchange rate and the associated market fundamentals from January 1974 through May 1984. West uses a different test in this paper than the one described above. He uses a construction similar to the variance bounds tests of Stephen LeRoy and Richard Porter (1981), which are discussed below, to conclude that exchange rate variability, in the absence of bubbles, is consistent with the standard monetary model assumed by Meese but augmented to include money demand errors - that is, other potential economic determinants of money demand,

\footnotetext{
${ }^{7}$ To our knowledge, Wing Woo wrote the first exchange-rate bubble paper, which was eventually published in 1987. Woo uses a portfolio balance model to test for bubbles in the exchange rate of the U.S. dollar versus the currencies of Germany, France, Canada and Japan. An interesting aspect of his investigation is that he takes a stand on the initiation mechanism for an exchange rate bubble by looking for bubbles just after major monetary disturbances. This method, probably more than most, runs the risk of confusing bubbles with expected changes in market fundamentals. We return to this possible confusion below. Additional bubble tests involving foreign exchange markets are by Kunio Okina (1985). Jeffrey Frankel (1985) and Paul Krugman (1986) develop empirical analyses that the value of the dollar relative to foreign currencies is not "sustainable." While they motivate their analyses by the strength of the dollar, which they attribute possibly to a bubble, they do not test formally for bubbles.
} 
and deviations from purchasing power parity as additional market fundamentals. West argues that Meese's conclusion that bubbles are present is premature in the sense that these additional features are not entertained by him. Their presence provides additional market fundamentals that may explain exchange rates without the addition of bubbles to the model. There are also additional criticisms of the Meese analysis that we discuss below.

\section{Bubbles and Stock Price Volatility}

This section examines the issues of bubbles in stock prices and the relation of bubble tests to excess volatility tests. A simple model that forms the foundation of much of the asset price bubble and excess volatility literature is the constant expected real return model presented near the start of this paper. ${ }^{8}$ Although many authors, including those of popular financial textbooks such as Richard Brealey and Stewart Myers (1981, pp. 42-45), often refer to this model as "a standard efficient markets model," it should be understood that it is quite restrictive. This is only a simple characterization of what one could mean by the concept of an efficient market. ${ }^{9}$ Since we think that people are averse to risk, we do not think that this simple model is a correct characterization of the actual economy. With risk aversion, there are good reasons why expected returns on assets would fluctuate even in an efficient market.

Although bubbles could make asset prices more volatile than their market fundamentals, certain kinds of asset price volatility tests are not well-designed to provide tests for bubbles. Gregory Mankiw, David Romer, and Matthew Shapiro (1985) note this point, and Robert Flood and Robert Hodrick (1986) elaborate upon it. The problem is that the specification of the null hypothesis underlying the tests includes bubbles, if they exist, into a composite null hypothesis. Consequently, rejection of the null hypothesis cannot be attributable to bubbles.

This point is easily understood by consideration of the construction of the volatility tests that have typically been conducted within the confines of the constant expected rate of return model. Robert Shiller (1981) proposes a comparison between the volatilities of actual prices and of what rational prices would have been with perfect foresight. He defines the perfect foresight rational price to be the discounted present value of actual dividends:

$$
q_{t}^{*}=\sum_{i=1}^{\infty}[1 /(1+r)]^{i} d_{t+i}
$$

The expected value of the right-hand side of equation (10) is the market fundamental price of the asset, and the validity of the constant expected return model can be tested

\footnotetext{
${ }^{8}$ See Robert Shiller's article in this issue and the critical survey by Christian Gilles and Stephen LeRoy (1987) for additional viewpoints

${ }^{9}$ See Eugene Fama (1976) for a discussion of the fact that market efficiency is always a joint hypothesis that depends on a model of appropriate expected asset returns and on an information set of investors.
} 
by examination of the null hypothesis that $q_{t}=E_{t}\left(q_{t}^{*}\right)$. Since the realization of a variable can be decomposed into its expectation conditional on a given information set plus an innovation that is not correlated with the information set, the validity of the model also implies the variance bound inequality $V\left(q_{t}\right) \leq V\left(q_{t}^{*}\right)$, if the unconditional variance is well defined.

Notice that since it is impossible to measure the right-hand side of equation (10), econometric analysis must infer measurements of the discounted future value of dividends. Sanford Grossman and Robert Shiller's (1981) measurable price, $\hat{q}_{t}$, truncates the infinite discounted sum of dividends in the last period of the sample, say at time $T$, and substitutes the discounted market price at time $T$ for the indefinite future. With this definition, the actual market price, conditional on the validity of the model, is the expected value of measurable rational price,

$$
\hat{q}_{t}=\sum_{i=1}^{T-t}[1 /(1+r)]^{i} d_{t+t}+[1 /(1+r)]^{T-t} q_{T}
$$

and the null hypothesis becomes $V\left(q_{t}\right) \leq V\left(\hat{q}_{t}\right)$. To understand why bubbles are included in this null hypothesis, notice that inclusion of $q_{T}=q_{T}^{f}+B_{T}$ on the right-hand side of equation (11) implies that $q_{t}=E_{t}\left(\hat{q}_{t}\right)$ even if bubbles are present because $q_{t}=q_{t}^{f}+B_{t}$, and bubbles are expected to grow each period such that $E_{t}\left(B_{T}\right)=(1+r)^{T-t} B_{t}$. Hence, these variance bounds tests are not well designed to test for bubbles and statistical evidence of violation of the variance bounds inequality in these tests cannot be taken as evidence of bubbles.

Shiller's (1981) first method of measuring the perfect foresight rational prices, on the other hand, substitutes the discounted average price during the sample as the forecast of the indefinite post-sample discounted sum of dividends. Unfortunately, there is no reason why the hypothesis that market price is equal to expected perfect foresight rational price should continue to be satisfied by this construction. Furthermore, Terry Marsh and Robert Merton (1986) demonstrate that this construction could have misleading properties if dividends are smoothed by management to be an exact function of current and past prices, since, by construction, the variance bound inequality must be violated when the ex post rational price is defined this way.

Much of Shiller's (1981) and Grossman and Shiller's (1981) evidence against the constant discount rate model is due to simple plots of the time series of actual prices and of constructed ex post rational prices. The plots of the time series of constructed ex post rational prices are considerably smoother than the time series of actual prices. Allan Kleidon (1986) effectively criticizes these plots by demonstrating that simulated data, generated to satisfy the model, produce plots that look very much like the plots from actual data. Kleidon's dividend process is the lognormal random walk. One reason the plots provide confusing evidence to the eye is that the perfect foresight price is highly serially correlated, even if dividends are stationary, and the eye cannot easily estimate the unconditional variance of such a process. Also, in Kleidon's case, 
dividends are actually nonstationary, which implies that the unconditional variance of price does not exist.

\section{West's Specification Test}

As noted above, Kenneth West (1987a) developed an ingenious test for bubbles. We now interpret the results of West's investigation of the Standard and Poor's Composite Price Index and the Dow-Jones data that were first used by Shiller (1981).

West uses the constant expected return model in testing the null hypothesis of no bubbles. He first conducts a battery of tests to check that the return equation (1) is consistent with the data, and he concludes that the evidence is not greatly at variance with the assumption. He next estimates a dividend forecasting equation in which future dividends depend upon the past history of dividends, and he checks its consistency with the data. As noted above, the West specification test compares the parameters in the projection of stock prices onto the information set of the dividend forecasting equation to the parameter estimates constructed to satisfy the HansenSargent (1981) formulas, which use the estimated $1 /(1+r)$ and the parameters of the dividend forecasting equation. Since there is a substantive difference in the two sets of estimates, West (1987a, p. 554) concludes, "The data reject the null hypothesis of no bubbles. The rejection appears to result at least in part because the coefficients in the regression of price on dividends are biased upwards."

One aspect of West's test is criticized by Flood, Hodrick and Paul Kaplan (1987). They note that estimation of $1 /(1+r)$ in the specification of the return generating model presented in equation (1) involves using only the one-period relation between current price and expected next period dividend and price, while testing the constructed relation of $1 /(1+r)$ and the parameters from the dividend forecasting model to the reduced form coefficients involves implicit iteration of the return generating model an infinite number of times as in the derivation of equations (2) and (3). Although West does not find strong evidence against the specification of the constant expected return model, when using the levels of real variables, Flood, Hodrick and Kaplan find substantive evidence of misspecification of the model when they iterate the equation for a second period. The latter authors change the specification in two other ways. They formulate the model in returns, and they use dividendprice ratios as instruments. ${ }^{10}$

West (1987a) acknowledges this significant evidence against his model of equilibrium expected returns when these alternative instruments are used. He also attempts to allow for time variation in expected returns within a linearized model with mixed results. The support for finding bubbles in some of his specifications increases while it decreases for others.

A second area of criticism of the West (1987a) specification test for bubbles is that he assumes the dividend forecasting equations are stationary in either the levels of

\footnotetext{
${ }^{10}$ These findings are consistent with the predictability of returns at long horizons that is documented by Eugene Fama and Kenneth French (1988), James Poterba and Lawrence Summers (1988), and John Campbell and Robert Shiller (1987, 1988a, b).
} 
real dividends or their first differences. Since most macroeconomic time series appear to be stationary in first differences of natural logarithms of the real variables, both of these specifications are somewhat suspect. In addition, the likelihood that a constant dividend process characterizes over 100 years of data seems somewhat small given what little is known about the dividend process. ${ }^{11}$

If we restrict attention to what West (1987a) actually estimates, for the Standard and Poor's composite dividend process from 1871 to 1980, the superior specification of the dividend process appears to require first differencing and a second order autoregression. When variability of returns is allowed, and the test statistics are recalculated, there is no evidence against the null hypothesis of no bubbles.

West (1987a) also notes that a popular model of the dividend process is the lognormal random walk. In this case a closed-form expression for the price of the stock is available in terms of $1 /(1+r)$ and the mean and variance of the growth rate of dividends. Since the asymptotic distribution theory necessary to provide a distribution for the coefficient in the projection of price onto dividends is inapplicable in this case, West does no formal tests. Although the point estimates of the model are inconsistent with the no bubbles hypothesis, the results are sensitive to the value of $r$, and the no bubbles hypothesis cannot be rejected for plausible values of $r$. Since there is sensitivity of the test to the estimated parameters, West interprets the results as mild evidence against the null of no bubbles. But the evidence seems just as easily interpretable in the opposite way, especially in light of potential for misspecification of the model.

\section{Recent Evidence on Stock Price Volatility}

We conclude this section with a discussion of some of the current literature on the excess variability of stock prices relative to dividends. A number of authors including Mankiw, Romer and Shapiro (1985), West (1988a), and Campbell and Shiller $(1988 \mathrm{a}, \mathrm{b})$ test implications of the variability of stock prices relative to dividends. All find that simple models such as the constant expected return model are inconsistent with the data. The sensitivity of these tests to the assumed structure of the dividend process and the model of returns is an outstanding issue for research. ${ }^{12}$

Examples of recent findings that intrigue us include the Campbell and Shiller (1988a, b) studies and the West (1988a) volatility tests. Campbell and Shiller (1988a, b) estimate a vector autoregression (VAR) of the logarithm of the dividend-price ratio,

\footnotetext{
${ }^{11}$ Terry Marsh and Robert Merton (1987) investigate the aggregate dividend process and conclude that there is support for the idea that managers smooth dividends. They argue that the only constraint on the dividend process is that its present value be equal to the present value of earnings. Campbell and Shiller (1987) question whether the findings of Marsh and Merton actually reflect dividend smoothing or simply additional ability of the market to predict future dividends from information that is in addition to the past history of dividends. Campbell and Shiller (1988a) note that a long average of the earnings of the Standard and Poor's composite relative to current price is useful in predicting dividends.

${ }^{12}$ Joe Mattey and Richard Meese (1986) investigate Monte Carlo simulations, using six different data generating environments, one of which includes a stochastic bubble, of twenty-four test statistics that have been proposed as tests of asset pricing models. Their results indicate that some tests may have poor small sample properties.
} 
the logarithm of a long average of earnings relative to price, and the first difference of the logarithm of dividends. The hypothesis of a constant expected rate of return then implies a restriction across the coefficients of the VAR that is easily rejected by the data. A by-product of the estimation is a ratio of the standard deviation of calculated returns that are constructed from the coefficients of the VAR assuming that the model is true relative to the standard deviation of actual returns. This value is 0.277 with a standard error of 0.069 . Thus, the false model's predicted returns are much less variable than actual returns. When the expected return on the stock market is allowed to be variable but is postulated to be equal to a constant plus the expected real return on commercial paper, the model is still rejected by the data at very low levels of significance, but the ratio of the standard deviation of returns implied by the model to the standard deviation of actual returns increases to 0.478 with a standard error of 0.044 .

West (1988a) develops a volatility test that is quite similar in its estimated equations to the specification test described above. The test involves a comparison of estimates, constructed using two different information sets, of the innovation variance in the expected infinite sum of current and future dividends discounted at a constant rate. One information set is taken to be current and past dividends, which is a proper subset of the market's information set. The other information set is taken to be the market price under the hypothesis that constant expected returns are correct. Forecasting with a smaller information set than the market's ought to result in a larger innovation variance, but West finds the opposite and attributes a large part of the volatility of prices to either bubbles or fads. He argues that time-varying expected returns are unlikely to overturn the results.

Whether the actual volatility of equity returns is due to time variation in the rational equity risk premium or to bubbles, fads, and market inefficiencies is an open issue. ${ }^{13}$ Bubble tests require a well-specified model of equilibrium expected returns that has yet to be developed, and this makes inference about bubbles quite tenuous.

\section{Some Matters of Interpretation}

Flood and Garber (1980b) note that an omitted variable problem can bias bubble tests toward rejection of the no bubbles hypothesis. Consider the possibility that agents may have been expecting some future event, which is relevant to the determination of the price level, that the unwary researcher does not include in the model's market fundamentals. For example, suppose agents had information during the sample that there would be an increase in the money supply at some future date, and suppose that this information is not imbedded in the historical money supply statistics used by the researcher to generate forecasts of future money supplies. In this circumstance the dynamics of the price level will rationally have anticipated the increase in the money supply in a manner that is indistinguishable from the dynamics

${ }^{13}$ See Colin Camerer (1987) and West (1988b) for further discussion of these issues. 
induced by a bubble in the market. The structure of a rational expectations model of the price level forces the dynamics of the price level in response to all omitted expected future variables to be indistinguishable from dynamic paths caused by bubbles. Flood and Hodrick (1986) demonstrate the analogous point in an equity market example in which agents are anticipating a change in taxation of dividend income. ${ }^{14}$

Consider the biases that could plague West's (1987a) stock price bubble test. Applications of the specification test for bubbles require a forecasting equation based on a subset of the agents' information set and an unrejected return generating process. West (1987a) uses ARIMA models of dividends and tests for changes in the structure of the dividend process with a Chow test. Since he cannot reject the hypothesis of no difference in the structure of the dividend process, he proceeds with the bubble test, but this does not mean that agents were not anticipating a change in the structure of dividends that did not materialize during the sample. Similarly, although West is unable to reject the hypothesis that his return generating process is correctly specified, we note above that extension of the model to longer horizons points strongly toward model misspecification. How this misspecification biases his tests is an open issue.

Similar problems plague the study of hyperinflations if agents think that a hyperinflation will not last indefinitely, since they consequently must be anticipating a reform of the monetary process. ${ }^{15}$ In such an environment, the price level is changing with changes in the probability of monetary reform, and without modelling this issue, researchers may associate movements in the price level caused by changes in the probability of monetary reform with changes induced by a nonexistent bubble.

In the foreign exchange market, a large body of research initiated by Richard Meese and Kenneth Rogoff (1983) indicates that standard exchange rate models forecast quite badly. As noted above, when bubble tests are conducted on these models, they find bubbles. According to much research, though, it is very unlikely that the models are correct. If the models are false, rejection of the null hypothesis of no bubbles cannot be attributed solely to bubbles since it could equally well be caused by the misspecification of the model.

The moral of this section is that research ought to find apparent evidence of bubbles when models work poorly or when agents expect the future to be somewhat different than history. We think this point presents a serious interpretive problem for all bubble tests. The current empirical tests for bubbles do not successfully establish the case that bubbles exist in asset prices. Nevertheless, bubble tests are interesting specification tests and should continue to be an important part of the econometrician's tool kit.

\footnotetext{
${ }^{14}$ James Hamilton and Charles Whiteman (1985) extend this omitted variable argument by formally demonstrating the observational equivalence of omitted state variables and stochastic bubbles.

${ }^{15}$ Flood and Garber (1980a) derive probabilities of monetary reform during the German hyperinflation by identifying them with the probability that the process for the money supply is inconsistent with a finite price level. Inconsistency is defined to be a monetary growth rate that is too fast to be discounted at the discount rate implied by the model. Such a money supply process implies an infinite price level if agents thought that it would last forever.
} 
This research was supported by a grant from The Lynde and Harry Bradley Foundation to whom the authors express their gratitude. The comments of John Cochrane, Mark Watson and the editor, Joseph E. Stiglitz, the co-editor, Carl Shapiro, and the managing editor, Timothy Taylor, are also grateful acknowledged.

\section{References}

Barro, Robert J., "The Ricardian Approach to Budget Deficits," Journal of Economic Perspectives, 1989, 3, 37-54.

Blanchard, Olivier J., "Speculative Bubbles, Crashes and Rational Expectations," Economics Letters, 1979, 3, 387-89.

Blanchard, Olivier J., and Mark W. Watson, "Bubbles, Rational Expectations and Financial Markets." In Wachtel, Paul, ed., Crisis in the Economic and Financial System. Lexington, MA: Lexington Books, 1982, pp. 295-315.

Brealey, Richard, and Stewart Myers, Principles of Corporate Finance. New York: McGraw-Hill, 1981.

Brock, William A., "Money and Growth: The Case of Long-run Perfect Foresight," International Economic Review, October 1974, 15, 750-777.

Brock, William A., "Asset Prices in a Production Economy." In McCall, John, ed., The Economics of Information and Uncertainty. Chicago: University of Chicago Press, 1982, pp. 1-43.

Burmeister, Edwin, Robert P. Flood, and Peter M. Garber, "On the Equivalence of Solutions in Rational Expectations Models," Journal of Economic Dynamics and Control, May 1983, 5, 224-234.

Burmeister, Edwin, and Kent Wall, "Kalman Filtering Estimation of Unobserved Rational Expectations with an Application to the German Hyperinflation," Journal of Econometrics, November 1982, 20, 255-84.

Cagan, Phillip, "The Monetary Dynamics of Hyperinflation." In Friedman, Milton, ed., Studies in the Quantity Theory of Money. Chicago: University of Chicago Press, 1956.

Camerer, Colin, "Bubbles and Fads in Asset Prices: A Review of Theory and Evidence," unpublished paper, University of Pennsylvania, 1987.

Campbell, John Y., and Robert J. Shiller, "Cointegration and Tests of Present Value Models," Journal of Political Economy, October 1987, 95, 1062-1088.

Campbell, John Y., and Robert J. Shiller, "Stock Prices, Earnings and Expected Dividends," Journal of Finance, July 1988a, 43, 661-676.
Campbell, John Y., and Robert J. Shiller, "The Dividend-Price Ratio and Expectations of Future Dividends and Discount Factors," Review of Financial Studies, Fall 1988b, l, 195-228.

Casella, Alessandra, "Testing for Price Level Bubbles: The German Hyperinflation Once More," unpublished paper, University of California, Berkeley, December 1986.

Diba, Behzad T., and Herschel I. Grossman, "On the Inception of Rational Bubbles," Quarterly Journal of Economics, August 1987, 102, 697-700.

Diba, Behzad T., and Herschel I. Grossman, "Rational Inflationary Bubbles," Journal of Monetary Economics, May 1988, 21, 35-46.

Fama, Eugene F., Foundations of Finance. New York: Basic Books, 1976.

Fama, Eugene F., and Kenneth R. French, "Permanent and Temporary Components of Stock Prices," Journal of Political Economy, April 1988, 96, 246-273.

Flood, Robert P., and Peter M. Garber, "An Economic Theory of Monetary Reform," Journal of Political Economy, February 1980a, 88, 24-58.

Flood, Robert P., and Peter M. Garber, "Market Fundamentals Versus Price Level Bubbles: The First Tests," Journal of Political Economy, August 1980b, 88, 745-70.

Flood, Robert P., Peter M. Garber, and Louis Scott, "Multi-Country Tests for Price Level Bubbles," Journal of Economic Dynamics and Control, December 1984, 8, 329-40.

Flood, Robert P., and Robert J. Hodrick, "Asset Price Volatility, Bubbles and Process Switching," Journal of Finance, September 1986, 41, 831-842.

Flood, Robert P., Robert J. Hodrick, and Paul Kaplan, "An Evaluation of Recent Evidence on Stock Market Bubbles," unpublished paper, Northwestern University, revised May 1987.

Frankel, Jeffrey A., "The Dazzling Dollar," Brookings Papers on Economic Activity, 1985, I, 199-217.

Garber, Peter M., "Tulipmania," Journal of Political Economy, June 1989, 97, 535-560. 
Gilles, Christian, and Stephen F. LeRoy, "The Variance-Bounds Tests: A Critical Survey," unpublished paper, University of California, Santa Barbara, August 1987.

Grossman, Sanford, and Robert J. Shiller, "The Determinants of the Variability of Stock Market Prices," American Economic Review, May 1981, 71, 222-27.

Hamilton, James D., and Charles H. Whiteman, "The Observable Implications of Selffulfilling Expectations," Journal of Monetary Economics, November 1985, 16, 353-74.

Hansen, Lars Peter, and Thomas J. Sargent, "Formulating and Estimating Dynamic Linear Rational Expectations Models." In Lucas, Robert E. Jr., and Thomas J. Sargent, eds., Rational Expectations and Econometric Practice. Minneapolis: University of Minnesota Press, 1981, pp. 91-126.

Hausman, Jerry A., "Specification Tests in Econometrics," Econometrica, November 1978, 46, $1251-71$.

Keynes, John Maynard, The General Theory of Employment, Interest and Money. London: Macmillan, 1936.

Kindleberger, Charles, Manias, Panics and Crashes. New York: Basic Books, 1978.

Kleidon, Allan W., "Variance Bounds Tests and Stock Price Valuation Models," Journal of Political Economy, October 1986, 94, 953-1001.

Krugman, Paul R., "Is the Strong Dollar Sustainable?" In The U.S. Dollar-Recent Developments, Outlook, and Policy Options. Federal Reserve Bank of Kansas City, 1986, pp. 103-132.

LeRoy, Stephen F., and Richard D. Porter, "The Present Value Relation: Tests Based on Implied Variance Bounds," Econometrica, May 1981, 49, 555-74.

Mankiw, N. Gregory, David Romer, and Matthew Shapiro, "An Unbiased Reexamination of Stock Market Volatility," The Journal of Finance, July 1985, 40, 677-89.

Marsh, Terry A., and Robert C. Merton, "Dividend Variability and Variance Bounds Tests for the Rationality of Stock Market Prices," American Economic Review, June 1986, 76, 483-498.

Marsh, Terry A., and Robert C. Merton, "Dividend Behavior for the Aggregate Stock Market," Journal of Business, January 1987, 60, 1-40.

Mattey, Joe, and Richard A. Meese, "Empirical Assessment of Present Value Relations," Econometric Reviews, 1986, 5, 171-234.

Meese, Richard A., "Testing for Bubbles in Exchange Markets: The Case of Sparkling Rates," Journal of Political Economy, April 1986, 94, 345-73.

Meese, Richard A., and Kenneth Rogoff, "Empirical Exchange Rate Models of the Seven- ties: Do They Fit Out of Sample?" Journal of International Economics, February 1983, 14, 3-24.

Obstfeld, Maurice, and Kenneth Rogoff, "Speculative Hyperinflations in Maximizing Models: Can We Rule Them Out?" Journal of Political Economy, August 1983, 91, 675-87.

Obstfeld, Maurice, and Kenneth Rogoff, "Ruling Out Divergent Speculative Bubbles," Journal of Monetary Economics, May 1986, 17, 349-62.

Okina, Kunio, "Empirical Tests of 'Bubbles' in the Foreign Exchange Market," Bank of Japan Monetary and Economic Studies, May 1985, 3, 1-45.

Poterba, James M., and Lawrence $\mathbf{H}$. Summers, "Mean Reversion in Stock Prices: Evidence and Implications," Journal of Financial Economics, October 1988, 22, 27-59.

Shiller, Robert J., "Rational Expectations and the Dynamic Structure of Macroeconomic Models: A Critical Review," Journal of Monetary Economics, January 1978, 4, 1-44.

Shiller, Robert J., "Do Stock Prices Move By Too Much to be Justified by Subsequent Changes in Dividends?" American Economic Review, June 1981, 71, 421-36.

Singleton, Kenneth J., "Speculation and the Volatility of Foreign Currency Exchange Rates." In Brunner, Karl, and Allan H. Meltzer, eds., Bubbles and Other Essays, Carnegie-Rochester Conference on Public Policy, Spring 1987, 26, 9-56.

Taylor, John, "Conditions for Unique Solutions in Stochastic Macroeconomic Models with Rational Expectations," Econometrica, November 1977, 45, 1377-1385.

Tirole, Jean, "On the Possibility of Speculation Under Rational Expectations," Econometrica, September 1982, 50, 1163-1181.

Tirole, Jean, "Asset Bubbles and Overlapping Generations," Econometrica, November 1985, 53, 1499-1528.

West, Kenneth D., "A Specification Test for Speculative Bubbles," Quarterly Journal of Economics, August 1987a, 102, 553-580.

West, Kenneth D., “A Standard Monetary Model and the Variability of the DeutschemarkDollar Exchange Rate," Journal of International Economics, August 1987b, 23, 57-76.

West, Kenneth, D., "Dividend Innovations and Stock Price Volatility," Econometrica, January 1988a, 56, 37-61.

West, Kenneth D., "Bubbles, Fads and Stock Price Volatility Tests: A Partial Evaluation," Journal of Finance, July 1988b, 43, 639-656.

Woo, Wing T., "Some Evidence of Speculative Bubbles in the Foreign Exchange Markets," Journal of Money, Credit and Banking, November 1987, 19, 499-514. 
http://www.jstor.org

\title{
LINKED CITATIONS
}

- Page 1 of 8 -

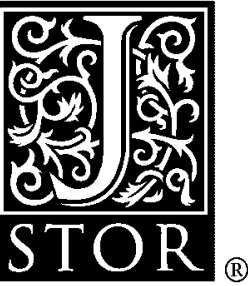

You have printed the following article:

On Testing for Speculative Bubbles

Robert P. Flood; Robert J. Hodrick

The Journal of Economic Perspectives, Vol. 4, No. 2. (Spring, 1990), pp. 85-101.

Stable URL:

http://links.jstor.org/sici?sici=0895-3309\%28199021\%294\%3A2\%3C85\%3AOTFSB\%3E2.0.CO\%3B2-1

This article references the following linked citations. If you are trying to access articles from an off-campus location, you may be required to first logon via your library web site to access JSTOR. Please visit your library's website or contact a librarian to learn about options for remote access to JSTOR.

\section{[Footnotes]}

\author{
${ }^{3}$ The Ricardian Approach to Budget Deficits \\ Robert J. Barro \\ The Journal of Economic Perspectives, Vol. 3, No. 2. (Spring, 1989), pp. 37-54. \\ Stable URL: \\ http://links.jstor.org/sici?sici=0895-3309\%28198921\%293\%3A2\%3C37\%3ATRATBD\%3E2.0.CO\%3B2-7 \\ ${ }^{5}$ Speculative Hyperinflations in Maximizing Models: Can We Rule Them Out? \\ Maurice Obstfeld; Kenneth Rogoff \\ The Journal of Political Economy, Vol. 91, No. 4. (Aug., 1983), pp. 675-687. \\ Stable URL: \\ http://links.jstor.org/sici?sici=0022-3808\%28198308\%2991\%3A4\%3C675\%3ASHIMMC\%3E2.0.CO\%3B2-C
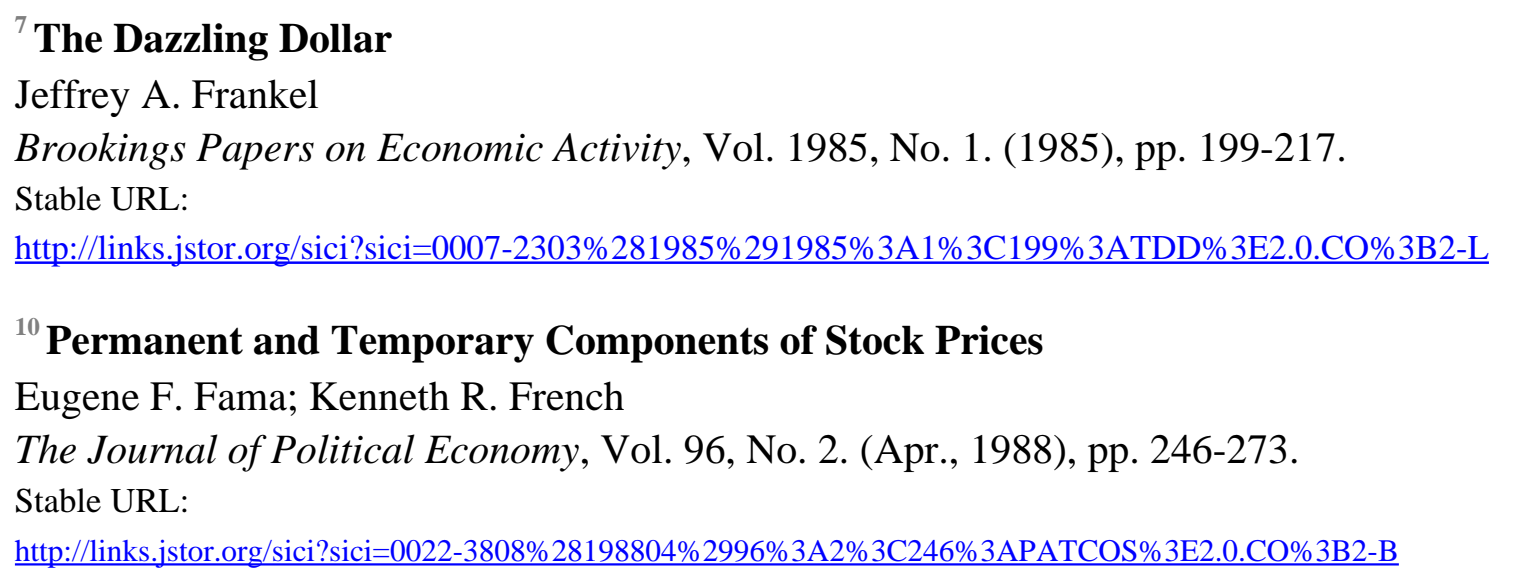

NOTE: The reference numbering from the original has been maintained in this citation list. 
http://www.jstor.org

\section{LINKED CITATIONS}

- Page 2 of 8 -

\section{${ }^{10}$ Cointegration and Tests of Present Value Models}

John Y. Campbell; Robert J. Shiller

The Journal of Political Economy, Vol. 95, No. 5. (Oct., 1987), pp. 1062-1088.

Stable URL:

http://links.jstor.org/sici?sici=0022-3808\%28198710\%2995\%3A5\%3C1062\%3ACATOPV\%3E2.0.CO\%3B2-6

\section{${ }^{10}$ Stock Prices, Earnings, and Expected Dividends}

John Y. Campbell; Robert J. Shiller

The Journal of Finance, Vol. 43, No. 3, Papers and Proceedings of the Forty-Seventh Annual Meeting of the American Finance Association, Chicago, Illinois, December 28-30, 1987. (Jul., 1988), pp. 661-676.

Stable URL:

http://links.jstor.org/sici?sici=0022-1082\%28198807\%2943\%3A3\%3C661\%3ASPEAED\%3E2.0.CO\%3B2-1

\section{${ }^{10}$ The Dividend-Price Ratio and Expectations of Future Dividends and Discount Factors} John Y. Campbell; Robert J. Shiller

The Review of Financial Studies, Vol. 1, No. 3. (Autumn, 1988), pp. 195-228.

Stable URL:

http://links.jstor.org/sici?sici=0893-9454\%28198823\%291\%3A3\%3C195\%3ATDRAEO\%3E2.0.CO\%3B2-O

\section{${ }^{11}$ Dividend Behavior for the Aggregate Stock Market}

Terry A. Marsh; Robert C. Merton

The Journal of Business, Vol. 60, No. 1. (Jan., 1987), pp. 1-40.

Stable URL:

http://links.jstor.org/sici?sici=0021-9398\%28198701\%2960\%3A1\%3C1\%3ADBFTAS\%3E2.0.CO\%3B2-7

\section{${ }^{11}$ Cointegration and Tests of Present Value Models}

John Y. Campbell; Robert J. Shiller

The Journal of Political Economy, Vol. 95, No. 5. (Oct., 1987), pp. 1062-1088.

Stable URL:

http://links.jstor.org/sici?sici=0022-3808\%28198710\%2995\%3A5\%3C1062\%3ACATOPV\%3E2.0.CO\%3B2-6

NOTE: The reference numbering from the original has been maintained in this citation list. 
http://www.jstor.org

\title{
LINKED CITATIONS
}

- Page 3 of 8 -

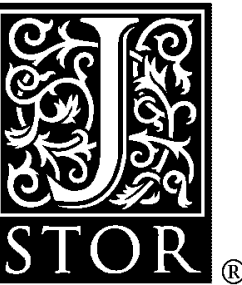

\footnotetext{
${ }^{11}$ Stock Prices, Earnings, and Expected Dividends

John Y. Campbell; Robert J. Shiller

The Journal of Finance, Vol. 43, No. 3, Papers and Proceedings of the Forty-Seventh Annual Meeting of the American Finance Association, Chicago, Illinois, December 28-30, 1987. (Jul., 1988), pp. 661-676.

Stable URL:

http://links.jstor.org/sici?sici=0022-1082\%28198807\%2943\%3A3\%3C661\%3ASPEAED\%3E2.0.CO\%3B2-1
}

\author{
${ }^{13}$ Bubbles, Fads and Stock Price Volatility Tests: A Partial Evaluation \\ Kenneth D. West \\ The Journal of Finance, Vol. 43, No. 3, Papers and Proceedings of the Forty-Seventh Annual \\ Meeting of the American Finance Association, Chicago, Illinois, December 28-30, 1987. (Jul., \\ 1988), pp. 639-656. \\ Stable URL: \\ http://links.jstor.org/sici?sici=0022-1082\%28198807\%2943\%3A3\%3C639\%3ABFASPV\%3E2.0.CO\%3B2-8

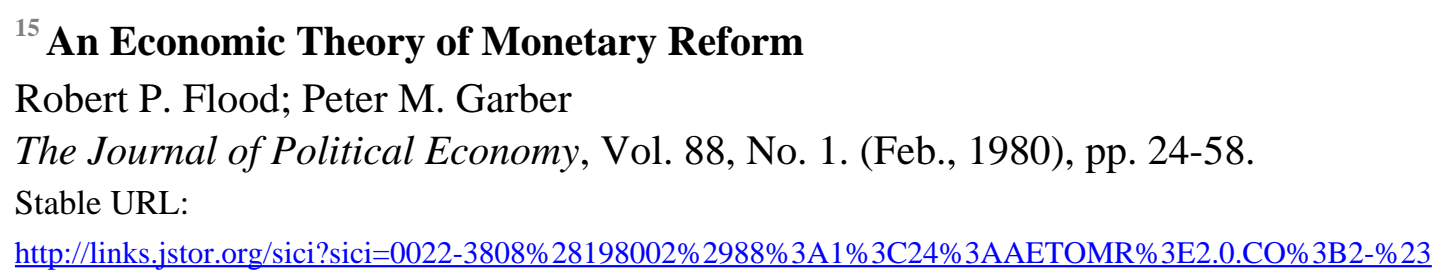

\section{References}

\section{The Ricardian Approach to Budget Deficits}

Robert J. Barro

The Journal of Economic Perspectives, Vol. 3, No. 2. (Spring, 1989), pp. 37-54.

Stable URL:

http://links.jstor.org/sici?sici=0895-3309\%28198921\%293\%3A2\%3C37\%3ATRATBD\%3E2.0.CO\%3B2-7

\section{Money and Growth: The Case of Long Run Perfect Foresight}

William A. Brock

International Economic Review, Vol. 15, No. 3. (Oct., 1974), pp. 750-777.

Stable URL:

http://links.jstor.org/sici?sici=0020-6598\%28197410\%2915\%3A3\%3C750\%3AMAGTCO\%3E2.0.CO\%3B2-J

NOTE: The reference numbering from the original has been maintained in this citation list. 
http://www.jstor.org

\section{LINKED CITATIONS}

- Page 4 of 8 -

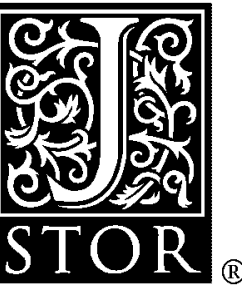

\section{Cointegration and Tests of Present Value Models}

John Y. Campbell; Robert J. Shiller

The Journal of Political Economy, Vol. 95, No. 5. (Oct., 1987), pp. 1062-1088.

Stable URL:

http://links.jstor.org/sici?sici=0022-3808\%28198710\%2995\%3A5\%3C1062\%3ACATOPV\%3E2.0.CO\%3B2-6

\section{Stock Prices, Earnings, and Expected Dividends}

John Y. Campbell; Robert J. Shiller

The Journal of Finance, Vol. 43, No. 3, Papers and Proceedings of the Forty-Seventh Annual Meeting of the American Finance Association, Chicago, Illinois, December 28-30, 1987. (Jul., 1988), pp. 661-676.

Stable URL:

http://links.jstor.org/sici?sici=0022-1082\%28198807\%2943\%3A3\%3C661\%3ASPEAED\%3E2.0.CO\%3B2-1

\section{The Dividend-Price Ratio and Expectations of Future Dividends and Discount Factors}

John Y. Campbell; Robert J. Shiller

The Review of Financial Studies, Vol. 1, No. 3. (Autumn, 1988), pp. 195-228.

Stable URL:

http://links.jstor.org/sici?sici=0893-9454\%28198823\%291\%3A3\%3C195\%3ATDRAEO\%3E2.0.CO\%3B2-O

\section{On the Inception of Rational Bubbles}

Behzad T. Diba; Herschel I. Grossman

The Quarterly Journal of Economics, Vol. 102, No. 3. (Aug., 1987), pp. 697-700.

Stable URL:

http://links.jstor.org/sici?sici=0033-5533\%28198708\%29102\%3A3\%3C697\%3AOTIORB\%3E2.0.CO\%3B2-\%23

\section{Permanent and Temporary Components of Stock Prices}

Eugene F. Fama; Kenneth R. French

The Journal of Political Economy, Vol. 96, No. 2. (Apr., 1988), pp. 246-273.

Stable URL:

http://links.jstor.org/sici?sici=0022-3808\%28198804\%2996\%3A2\%3C246\%3APATCOS\%3E2.0.CO\%3B2-B

\section{An Economic Theory of Monetary Reform}

Robert P. Flood; Peter M. Garber

The Journal of Political Economy, Vol. 88, No. 1. (Feb., 1980), pp. 24-58.

Stable URL:

http://links.jstor.org/sici?sici=0022-3808\%28198002\%2988\%3A1\%3C24\%3AAETOMR\%3E2.0.CO\%3B2-\%23

NOTE: The reference numbering from the original has been maintained in this citation list. 
http://www.jstor.org

\title{
LINKED CITATIONS
}

- Page 5 of 8 -

\section{Market Fundamentals versus Price-Level Bubbles: The First Tests}

Robert P. Flood; Peter M. Garber

The Journal of Political Economy, Vol. 88, No. 4. (Aug., 1980), pp. 745-770.

Stable URL:

http://links.jstor.org/sici?sici=0022-3808\%28198008\%2988\%3A4\%3C745\%3AMFVPBT\%3E2.0.CO\%3B2-C

\author{
Asset Price Volatility, Bubbles, and Process Switching \\ Robert P. Flood; Robert J. Hodrick \\ The Journal of Finance, Vol. 41, No. 4. (Sep., 1986), pp. 831-842. \\ Stable URL: \\ http://links.jstor.org/sici?sici=0022-1082\%28198609\%2941\%3A4\%3C831\%3AAPVBAP\%3E2.0.CO\%3B2-C
}

\section{The Dazzling Dollar}

Jeffrey A. Frankel

Brookings Papers on Economic Activity, Vol. 1985, No. 1. (1985), pp. 199-217.

Stable URL:

http://links.jstor.org/sici?sici=0007-2303\%281985\%291985\%3A1\%3C199\%3ATDD\%3E2.0.CO\%3B2-L

\section{Tulipmania}

Peter M. Garber

The Journal of Political Economy, Vol. 97, No. 3. (Jun., 1989), pp. 535-560.

Stable URL:

http://links.jstor.org/sici?sici=0022-3808\%28198906\%2997\%3A3\%3C535\%3AT\%3E2.0.CO\%3B2-F

\section{The Determinants of the Variability of Stock Market Prices}

Sanford J. Grossman; Robert J. Shiller

The American Economic Review, Vol. 71, No. 2, Papers and Proceedings of the Ninety-Third Annual Meeting of the American Economic Association. (May, 1981), pp. 222-227. Stable URL:

http://links.jstor.org/sici?sici=0002-8282\%28198105\%2971\%3A2\%3C222\%3ATDOTVO\%3E2.0.CO\%3B2-8

\section{Specification Tests in Econometrics}

J. A. Hausman

Econometrica, Vol. 46, No. 6. (Nov., 1978), pp. 1251-1271.

Stable URL:

http://links.jstor.org/sici?sici=0012-9682\%28197811\%2946\%3A6\%3C1251\%3ASTIE\%3E2.0.CO\%3B2-X

NOTE: The reference numbering from the original has been maintained in this citation list. 
http://www.jstor.org

\section{LINKED CITATIONS}

- Page 6 of 8 -

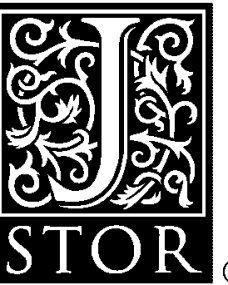

Variance Bounds Tests and Stock Price Valuation Models

Allan W. Kleidon

The Journal of Political Economy, Vol. 94, No. 5. (Oct., 1986), pp. 953-1001.

Stable URL:

http://links.jstor.org/sici?sici=0022-3808\%28198610\%2994\%3A5\%3C953\%3AVBTASP\%3E2.0.CO\%3B2-M

The Present-Value Relation: Tests Based on Implied Variance Bounds

Stephen F. LeRoy; Richard D. Porter

Econometrica, Vol. 49, No. 3. (May, 1981), pp. 555-574.

Stable URL:

http://links.jstor.org/sici?sici=0012-9682\%28198105\%2949\%3A3\%3C555\%3ATPRTBO\%3E2.0.CO\%3B2-3

Dividend Variability and Variance Bounds Tests for the Rationality of Stock Market Prices

Terry A. Marsh; Robert C. Merton

The American Economic Review, Vol. 76, No. 3. (Jun., 1986), pp. 483-498.

Stable URL:

http://links.jstor.org/sici?sici=0002-8282\%28198606\%2976\%3A3\%3C483\%3ADVAVBT\%3E2.0.CO\%3B2-C

\section{Dividend Behavior for the Aggregate Stock Market}

Terry A. Marsh; Robert C. Merton

The Journal of Business, Vol. 60, No. 1. (Jan., 1987), pp. 1-40.

Stable URL:

http://links.jstor.org/sici?sici=0021-9398\%28198701\%2960\%3A1\%3C1\%3ADBFTAS\%3E2.0.CO\%3B2-7

Testing for Bubbles in Exchange Markets: A Case of Sparkling Rates?

Richard A. Meese

The Journal of Political Economy, Vol. 94, No. 2. (Apr., 1986), pp. 345-373.

Stable URL:

http://links.jstor.org/sici?sici=0022-3808\%28198604\%2994\%3A2\%3C345\%3ATFBIEM\%3E2.0.CO\%3B2-S

Speculative Hyperinflations in Maximizing Models: Can We Rule Them Out?

Maurice Obstfeld; Kenneth Rogoff

The Journal of Political Economy, Vol. 91, No. 4. (Aug., 1983), pp. 675-687.

Stable URL:

http://links.jstor.org/sici?sici=0022-3808\%28198308\%2991\%3A4\%3C675\%3ASHIMMC\%3E2.0.CO\%3B2-C

NOTE: The reference numbering from the original has been maintained in this citation list. 
http://www.jstor.org

\section{LINKED CITATIONS}

- Page 7 of 8 -

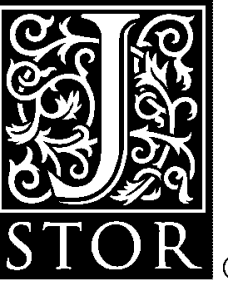

Do Stock Prices Move Too Much to be Justified by Subsequent Changes in Dividends? Robert J. Shiller

The American Economic Review, Vol. 71, No. 3. (Jun., 1981), pp. 421-436.

Stable URL:

http://links.jstor.org/sici?sici=0002-8282\%28198106\%2971\%3A3\%3C421\%3ADSPMTM\%3E2.0.CO\%3B2-2

Conditions for Unique Solutions in Stochastic Macroeconomic Models with Rational Expectations

John B. Taylor

Econometrica, Vol. 45, No. 6. (Sep., 1977), pp. 1377-1385.

Stable URL:

http://links.jstor.org/sici?sici=0012-9682\%28197709\%2945\%3A6\%3C1377\%3ACFUSIS\%3E2.0.CO\%3B2-W

On the Possibility of Speculation under Rational Expectations

Jean Tirole

Econometrica, Vol. 50, No. 5. (Sep., 1982), pp. 1163-1181.

Stable URL:

http://links.jstor.org/sici?sici=0012-9682\%28198209\%2950\%3A5\%3C1163\%3AOTPOSU\%3E2.0.CO\%3B2-7

\section{Asset Bubbles and Overlapping Generations}

Jean Tirole

Econometrica, Vol. 53, No. 6. (Nov., 1985), pp. 1499-1528.

Stable URL:

http://links.jstor.org/sici?sici=0012-9682\%28198511\%2953\%3A6\%3C1499\%3AABAOG\%3E2.0.CO\%3B2-N

\section{A Specification Test for Speculative Bubbles}

Kenneth D. West

The Quarterly Journal of Economics, Vol. 102, No. 3. (Aug., 1987), pp. 553-580.

Stable URL:

http://links.jstor.org/sici?sici=0033-5533\%28198708\%29102\%3A3\%3C553\%3AASTFSB\%3E2.0.CO\%3B2-B

\section{Dividend Innovations and Stock Price Volatility}

Kenneth D. West

Econometrica, Vol. 56, No. 1. (Jan., 1988), pp. 37-61.

Stable URL:

http://links.jstor.org/sici?sici=0012-9682\%28198801\%2956\%3A1\%3C37\%3ADIASPV\%3E2.0.CO\%3B2-M

NOTE: The reference numbering from the original has been maintained in this citation list. 
http://www.jstor.org

\section{LINKED CITATIONS \\ - Page 8 of 8 -}

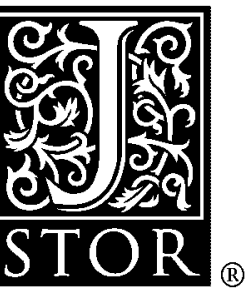

\section{Bubbles, Fads and Stock Price Volatility Tests: A Partial Evaluation}

Kenneth D. West

The Journal of Finance, Vol. 43, No. 3, Papers and Proceedings of the Forty-Seventh Annual Meeting of the American Finance Association, Chicago, Illinois, December 28-30, 1987. (Jul., 1988), pp. 639-656.

Stable URL:

http://links.jstor.org/sici?sici=0022-1082\%28198807\%2943\%3A3\%3C639\%3ABFASPV\%3E2.0.CO\%3B2-8

\section{Some Evidence of Speculative Bubbles in the Foreign Exchange Markets}

Wing Thye Woo

Journal of Money, Credit and Banking, Vol. 19, No. 4. (Nov., 1987), pp. 499-514.

Stable URL:

http://links.jstor.org/sici?sici=0022-2879\%28198711\%2919\%3A4\%3C499\%3ASEOSBI\%3E2.0.CO\%3B2-O

NOTE: The reference numbering from the original has been maintained in this citation list. 